\title{
Fault Tolerant-Control: Solutions and Challenges
}

\author{
Marcin Witczak, Marcin Pazera \\ University of Zielona Góra, Institute of Control and Computation Engineering, ul. Podgórna 50, 65-246 Zielona Góra
}

Abstract: Fault-Tolerant Control (FTC) systems are intensively investigated both from the theoretical and practical viewpoints. It is reflected in a large number of publications and research teams dealing with this emerging area. FTC is perceived as a technique integrating advanced fault diagnosis techniques and modern control methods that makes it possible a system to continue its mission under a faulty situation. It can be also observed that the fault diagnosis theory is well developed for linear systems. There are also approaches that can be efficiently used to minimize the uncertainty effect of the model of the system being controlled and diagnosed as well as noise and disturbances. This means that the development of analogous strategies for non-linear systems is fully justified. One of the main difficulties in the current development of FTC is the fact that most works presented in the literature treat fault diagnosis and FTC problems separately. Unfortunately, perfect fault diagnosis, and in particular fault identification, is impossible to attain. This justifies the necessity of developing integrated fault diagnosis and FTC, which takes into account such an unappealing phenomenon, both for linear and non-linear systems. As indicates the state-of-the-art regarding FTC, the integration issue is treated cursorily while the lack of suitable solution is replaced with a chain of (possibly conservative) assumptions related to fault diagnosis. Taking into account the above difficulties, the paper focuses on the presentation of modern FTC with analytical and soft computing approaches. An effective FTC methods are discussed along with the integration process of fault diagnosis and FTC.

Keywords: fault diagnosis, fault-tolerant control, fault, failure, robustness

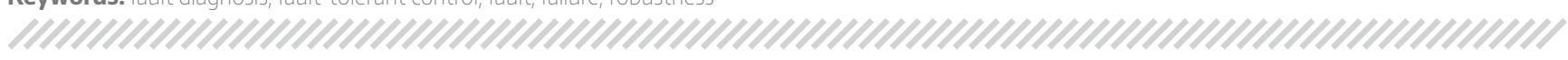

\section{Introduction}

An instant growth in the complexity, efficiency, and reliability of modern industrial systems necessitates new development in control and Fault Diagnosis (FD) [1-6] theory and practice. A fusion of these two strategies is intensively studied under the name Fault-Tolerant Control (FTC) [7-11] and reduces to a moderate integration of advanced fault diagnosis $[5,12,6]$ and control [1] techniques. A general FTC scheme is depicted in Figure 1 $[13,6]$.

It is an evident fact that the controlled system is the core part of the scheme. It can be divided into actu-

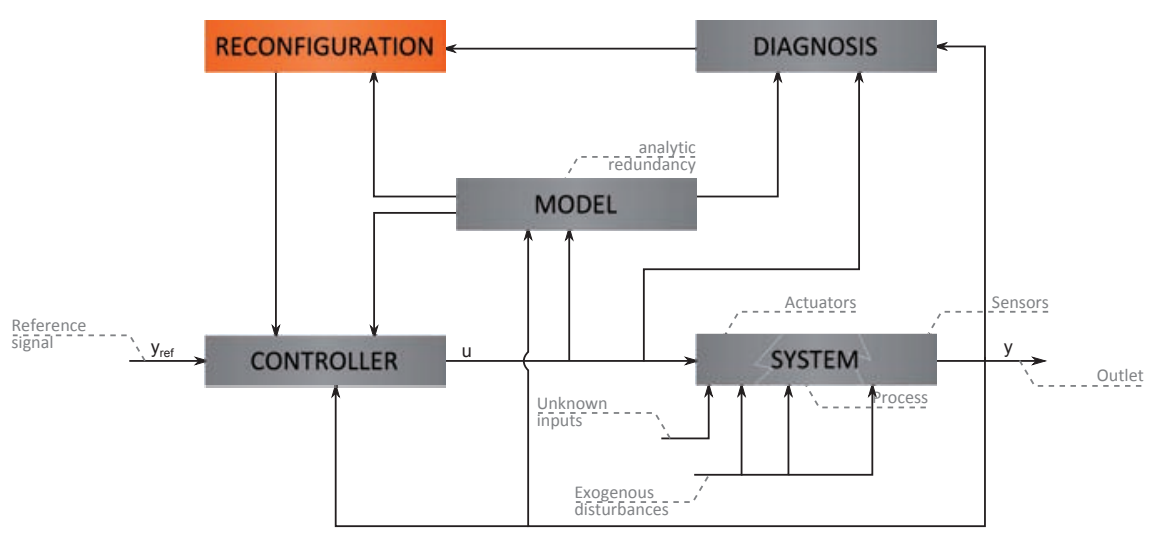

Fig. 1. Modern control system

Rys. 1. Nowoczesny układ sterowania
Autor korespondujący:

Marcin Witczak, M.Witczak@issi.uz.zgora.pl

Artykuł recenzowany

nadesłany 21.12.2015 r., przyjęty do druku 15.01.2016 r.

Zezwala się na korzystanie z artykułu na warunkach licencji Creative Commons Uznanie autorstwa 3.0 ators, process dynamics and sensors. Each of these parts is affected by the so-called unknown inputs, which consists of process and measurement noise as well as external disturbances acting on the system. When model-based control and analytical redundancy-based fault diagnosis are utilised $[1,2$, $5,7-10,6]$, then the unknown input can also be extended by model uncertainty, i.e., the mismatch between the model and the system being considered. 


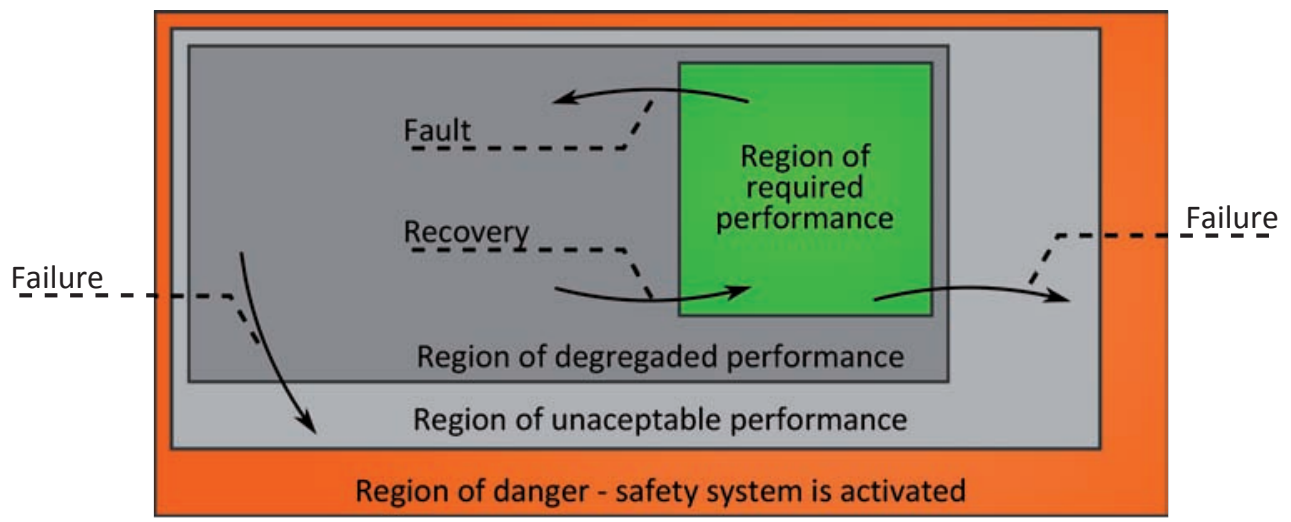

Fig. 2. Regions of system performance

Rys. 2. Obszary wydajności systemu

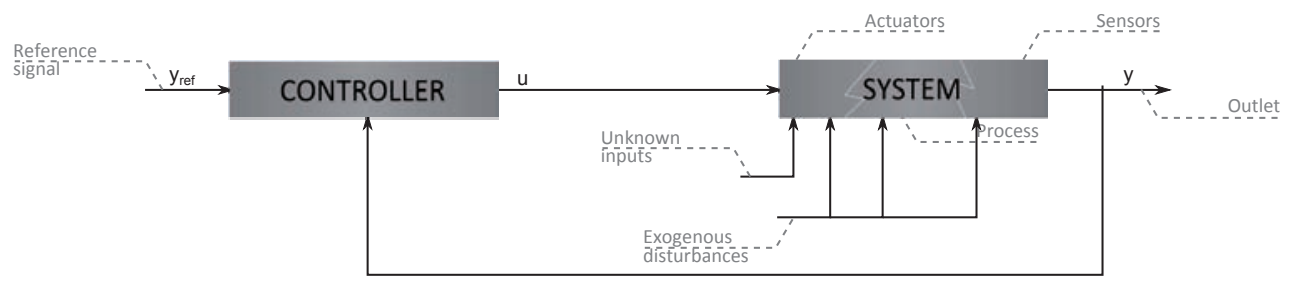

Fig. 3. Passive fault-tolerant controller

Rys. 3. Pasywny regulator tolerujący uszkodzenia

The system can also be affected by faults. This unappealing phenomenon can be defined as an unpermitted deviation of at least one characteristic property or parameter of the system from the normal condition, e.g., an actuator malfunction. On the other hand, the term failure pertains a complete breakdown of the system. Thus, the term fault stands for a malfunction rather than a catastrophe. Indeed, failure is a permanent interruption in the system ability of performing a required mission under specified operating conditions. Figure 2 presents possible system behaviours along with suitable FTC recovery actions that can bring the system performance back into the required performance.

Since the system can be split into three parts (Fig. 1), i.e., actuators, the process, and sensors, such a decomposition leads directly to three classes of faults $[2,11]$ :

- Actuator faults, which can be viewed as any malfunction of the equipment that actuates the system.

- Sensor faults, which can be viewed as serious measurements variations.

- Process faults (or component faults), which occur when some changes in the system make the dynamic relation invalid, e.g., a leak in a tank.

In the light of the above discussion, the main objective of the paper is to give an outline concerning the FTC solutions as well as to indicate challenges in this emerging research area. The paper is organized as follows. Section 2 gives a general overview of the existing approaches. Starting from passive FTC up to advanced virtual actuators and sensors, all approaches are briefly discussed. Subsequently, the original FTC research achievements of the authors are reviewed and detailed in Section 3 and 4, respectively. As a result of the undertaken discussion, the challenges concerning modern FTC are formulated and exhibited in Section 5.

\section{Overview of FTC Schemes}

\subsection{Passive FTC}

FTC systems can be divided two distinct classes $[15,11]$ - passive and active ones. In passive FTC [16-19], controllers are designed to be robust against a set of predefined faults, therefore there is no need for fault diagnosis. Therefore, the fault are treated in a similar fashion as disturbances. An obvious drawback of such an approach is the fact that a limited number of faults can be tolerated. Further, such a controller works sub-optimally for the nominal plant because its parameters are prearranged so as to get a trade-off between the performance and fault tolerance. It should be noted that the passive fault-tolerant controller is similar to the robust approach when uncertain systems are considered. Although the difference lies not only in the size and interpretation of faults versus uncertainties but also in the structure of the constraints resulting from the faults [1]. An overall structure of passive FTC is depicted in Fig. 3.

\subsection{Active FTC: Restructurable vs. Reconfigurable Approaches}

In contrast to passive ones, active FTC schemes react to the faults actively by reconfiguring control actions. This is realised in such a way as the system stability and acceptable performance is maintained. An active FTC, in the literature is sometimes also referred to as self-repairing, reconfigurable, restructurable, or self-healing control systems. To achieve fault tolerance, the control system relies heavily on fault diagnosis $[5,20,6]$. Hence, the main goal of the FTC system is to design the controller with an appropriate architecture, which enables stability and satisfactory performance, not only when all control components are healthy, but also in cases when there are faults in sensors, actuators, or other system components.

Usually, as depicted in Fig. 4, the FTC system can be divided into four sub-systems [15]:

- a reconfigurable controller,

- an FDD scheme,

- a controller reconfiguration scheme,

- a command/reference governor.

It should be noted that the inclusion of both fault diagnosis and a reconfigurable controller within the system structure is the main difference between the active and the passive FTC 
system. Hence, the key issue of a successful FTC scheme is to design a controller which can be easily reconfigured. Lastly, a reconfiguration mechanism must be able to recover as much as possible the pre-fault system performance taking into account all uncertainties and constraints present in the system.

As shown in Fig. 4, fault diagnosis must provide information about all detected faults in real time. Based on this information, the reconfiguration block must take into consideration the current system behavior, as well as to construct an appropriate post-fault system model. Afterwards, the reconfiguration data for the controller should be designed, in such a way that a currently faulty system is stabilized and fault propagation is stopped. The second objective is to recover as much of the nominal performance as possible. At the same time, the actuator saturation and other system constraints should be taken into consideration and the system trajectories adjusted if necessary. Such an FTC system is often classified as a reconfigurable one, though some authors call it an accommodation scheme [1].

However, in some cases reconfiguration of the controller is not enough to stabilize the faulty system. In such cases, the structure of the new controller must be changed. This restructuring also uses an alternative input and output signals in the new controller configuration. Afterwards, a new control law has to be designed on-line. Such an FTC controller is called a restructurable fault-tolerant controller, and is depicted in Fig. 5. This type of FTC is also sometimes called reconfiguration [1], but to avoid confusion the former terms will be used, i.e., reconfigurable versus restructurable.

\subsection{Virtual Sensors and Actuators}

Besides of the known problems related to fault diagnosis and FTC, study on the following topics is needed for establishing an efficient and effective framework of FTC technology [11]:

- advanced methods of system and/or controller reconfiguration,

- advanced fault diagnosis and control methods for nonlinear and uncertain systems,

- integrated design of fault diagnosis and reconfiguration mechanisms,

- analysis of switched behavior between two different configurations and development of switching schemes,

- implementation of reconfiguration mechanism under real time condition.

The above defined problems can partially be solved with the application of the so-called virtual sensors and actuators [21-23]. In the case of actuators, the approach rely on the idea of keeping the nominal controller in the loop and avoiding the complete controller redesign by placing a block between the controller output and the input of all available actuators (Fig. 6). The goal of this block is to provide a signal, which has the same effect as the broken actuator would have in the nominal system, therefore masking the fault. This is, of course, achieved by appropriate fault compensation and/or modifying suitably the nominal control strategy of fault-free actuators. That is why the approach can be perceived as a kind of virtual actuator [22, 24-27].

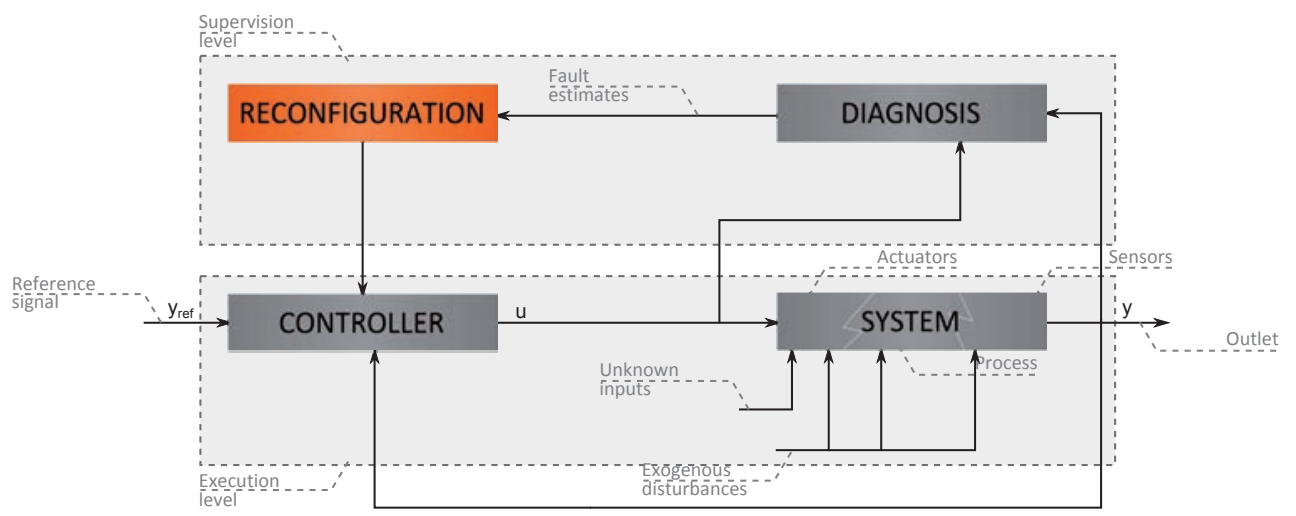

Fig. 4. Reconfigurable fault-tolerant controller

Rys. 4. Rekonfigurowalny regulator tolerujący uszkodzenia

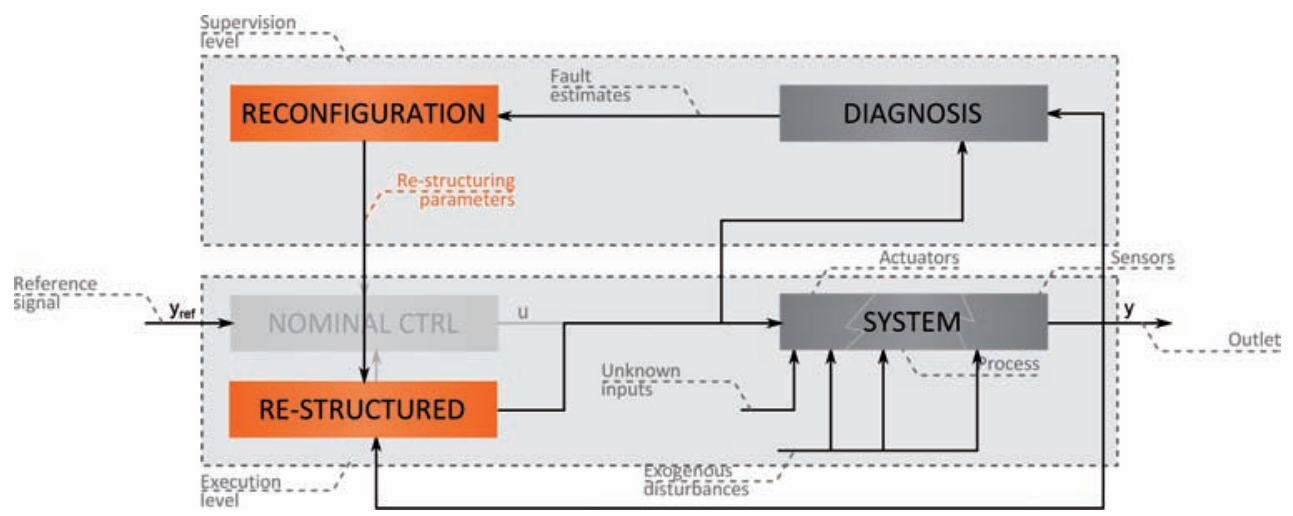

Fig. 5. Restructurable fault-tolerant controller

Rys. 5. Restrukturyzowalny regulator tolerujący uszkodzenia 


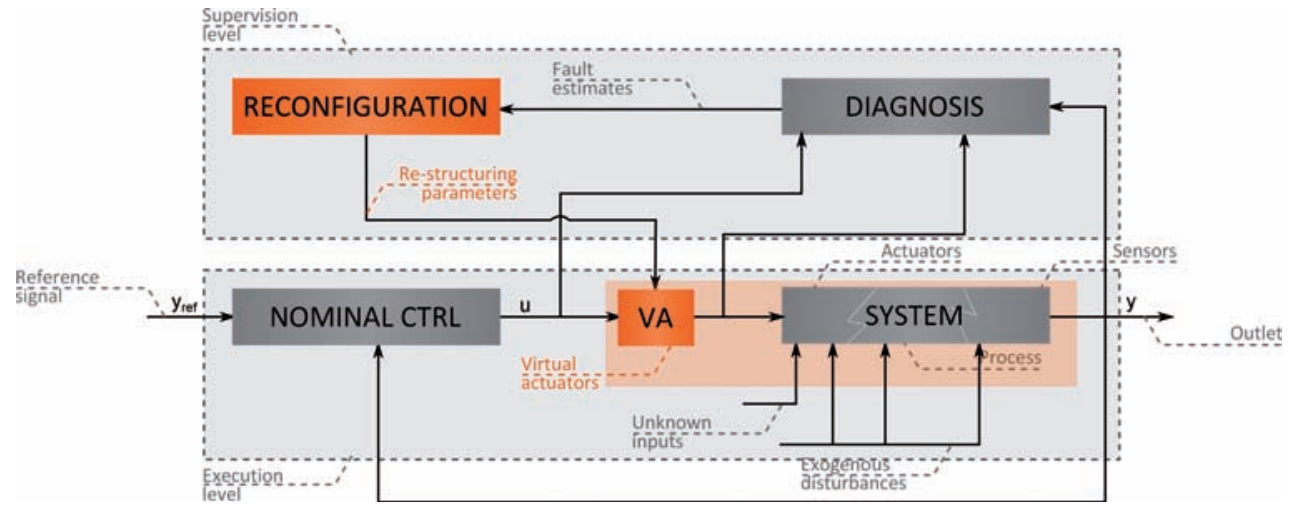

Fig. 6. Virtual actuator-based FTC

Rys. 6. FTC bazujące na wirtualnym urządzeniu wykonawczym

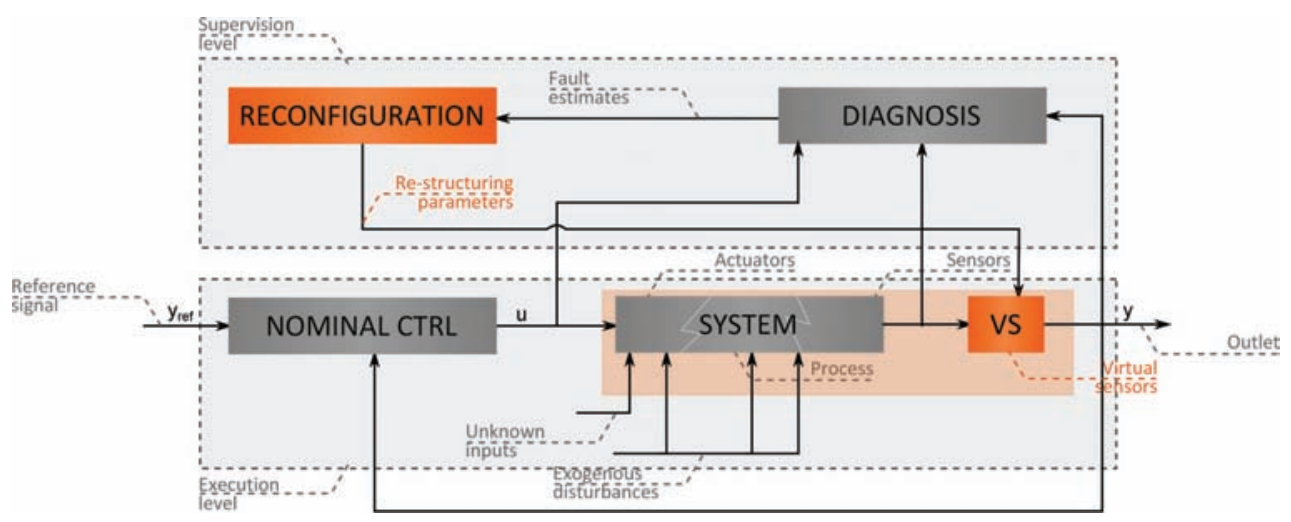

Fig. 7. Virtual sensor-based FTC

Rys. 7. FTC bazujące na wirtualnym czujniku pomiarowym

The main drawback of the approaches presented in the literature is that a perfect information about the faults is required (no fault estimation uncertainty). Another issue is the fact that they are designed for linear deterministic systems without taking into account modelling uncertainty, disturbances and system and control constraints that inevitable in real control systems. This can be realized with the so called virtual sensors $[21,28,11]$. After a sensor fault is detected and isolated, the FTC system is reconfigured to use all but corrupted sensor readings, while the output of the virtual sensor replaces the output of the faulty sensor (Fig. 7). After the sensor is repaired or replaced, the use of all sensors can be safely resumed. That is why the proposed strategy is called a virtual sensor.

In both cases (virtual sensors and actuator), their performance is strongly related with fault diagnosis quality. Thus, the better the fault estimation the better results provided by virtual sensors and actuator. In the light of this comment, the objective of the subsequent section is to discuss recent advances in this emerging area.

\section{Fault Estimation}

Fault estimation has been addressed using various strategies, e.g.: augmenting the state vector by an unknown input, two-stage Kalman filter [29], minimum variance input and state estimator [30, 31], adaptive estimation [32], sliding mode high-gain observers [33] and finally, an $H_{\infty}$ approach [34]. The fault estimation can also be formulated as a parameter estimation problem [35] leading to the application of parameter estimation algorithms. For example, [36] proposed a unified framework based on a model reference approach for non-linear systems that can be represented by means of Takagi-Sugeno models. In [37], a fault estimation scheme for linear parameter-varying systems is presented. In [38], an observer scheme that estimates simultaneously the state and the fault is proposed. For non-linear systems, the observer-based FDI approaches have gained a lot of interest [39, 40] and FDI formulations for some classes of nonlinear systems have been derived. In [41], state affine nonlinear systems have been handled, and in [41, 42], the class of input-affine systems has been considered, among others. The work [43] presents a detailed geometric description of how to tackle the residual generation problem for non-linear systems. On the other hand, [44] presents a procedure to design a bank of extended $H_{\infty}$ observers for sensor FDI for a certain class of non-linear systems. There are also approaches that employ soft computing techniques, e.g., neural networks [45].

Taking into account the above discussion, let us consider a non-linear discrete-time system

$$
\begin{gathered}
\boldsymbol{x}_{k+1}=\boldsymbol{A} \boldsymbol{x}_{k}+\boldsymbol{B} \boldsymbol{u}_{k}+\boldsymbol{D} \boldsymbol{d}_{k}+g\left(\boldsymbol{x}_{k}, \boldsymbol{u}_{k}\right)+\boldsymbol{B} \boldsymbol{f}_{a, k}+\boldsymbol{W}_{1} \boldsymbol{w}_{k} \\
\boldsymbol{y}_{k}=\boldsymbol{C} \boldsymbol{x}_{k}+\boldsymbol{f}_{s, k}+\boldsymbol{W}_{2} \boldsymbol{w}_{k}
\end{gathered}
$$

where $\boldsymbol{x}_{k} \in X \subset \mathbb{R}^{n}$ is the state, $\boldsymbol{u}_{k} \in U \subset \mathbb{R}^{r}$ stands for the input, $\boldsymbol{y}_{k} \in \mathbb{R}^{m}$ denotes the output, $\boldsymbol{f}_{a, k} \in \mathbb{R}^{r}$ stands for the actuator fault $\boldsymbol{f}_{s, k} \in \mathbb{R}^{m}$ denotes the sensor fault, $\boldsymbol{d}_{k} \in \mathbb{R}^{q}$ is the unknown input disturbance, $\boldsymbol{w}_{k}$ is an exogenous disturbance vector. Considering 
the system model (1)-(2), the problem is to design an observer that will be able to estimate simultaneously the state $\boldsymbol{x}_{k}$ and the faults $\boldsymbol{f}_{a, k}$ and $\boldsymbol{f}_{s, k}$, as well as decouple the effect of the unknown input $\boldsymbol{d}_{k}$ while minimizing the influence of $\boldsymbol{w}_{k}$.

As it was already mentioned, FTC, and in particular, virtual sensor and actuator strategies are based on information about faults. Thus, the solution to the above problem constitutes the preliminary step towards an efficient FTC. On the other hand, the problem is not trivial and its solution for the actuator fault case was provided recently by Witczak et al. [46]. For that purpose, the following structure was proposed along with a suitable computational algorithm:

$$
\begin{gathered}
\boldsymbol{z}_{k+1}=\boldsymbol{N} \boldsymbol{z}_{k}+\boldsymbol{G} \boldsymbol{u}_{k}+\boldsymbol{L} \boldsymbol{y}_{k}+\boldsymbol{T} \boldsymbol{B} \hat{\boldsymbol{f}}_{a, k}+\boldsymbol{T} g\left(\hat{\boldsymbol{x}}_{k}, \boldsymbol{u}_{k}\right) \\
\hat{\boldsymbol{x}}_{k}=\boldsymbol{z}_{k}-\boldsymbol{E} \boldsymbol{y}_{k} \\
\hat{\boldsymbol{f}}_{k+1}=\hat{\boldsymbol{f}}_{k}+\boldsymbol{F}\left(\boldsymbol{y}_{k}-\boldsymbol{C} \hat{\boldsymbol{x}}_{k}\right)
\end{gathered}
$$

where $\hat{\boldsymbol{x}}_{k}$ and $\hat{\boldsymbol{f}}_{k}$ are the state and fault estimates, respectively.

Note that the sensor fault can also be estimated with the above approach but it requires suitable technical manipulations. For the purpose of simplicity, the scheme for simultaneous sensor and actuator fault is presented for linear systems of the form:

$$
\begin{gathered}
\overline{\boldsymbol{x}}_{k+1}=\overline{\boldsymbol{A}} \overline{\boldsymbol{x}}_{k}+\overline{\boldsymbol{B}} \boldsymbol{u}_{k}+\overline{\boldsymbol{B}} \boldsymbol{f}_{a, k}+\overline{\boldsymbol{W}_{1}} \boldsymbol{w}_{k} \\
\overline{\boldsymbol{y}}_{k}=\overline{\boldsymbol{C}} \overline{\boldsymbol{x}}_{k}+\overline{\boldsymbol{C}}_{f} \boldsymbol{f}_{s, k}+\overline{\boldsymbol{W}_{2}} \boldsymbol{w}_{k}
\end{gathered}
$$

where: $\overline{\boldsymbol{x}}_{k} \in \mathbb{R}^{n}, \boldsymbol{u}_{k} \in \mathbb{R}^{r}, \overline{\boldsymbol{y}}_{k} \in \mathbb{R}^{m}$, denote the state, input and output, respectively.

The objective of further deliberations is to design a scheme that will be able to simultaneously estimate the system state along with the sensor and actuator fault, respectively. To settle this problem, let us consider a filter of the form:

$$
\boldsymbol{s}_{k+1}=\boldsymbol{D}\left(\overline{\boldsymbol{y}}_{k}-\boldsymbol{s}_{k}\right)
$$

where $\boldsymbol{D} \in \mathbb{R}^{m \times m}$ is a matrix with eigenvalues lying within a unit circle. Substituting (7) into (8) gives:

$$
\boldsymbol{s}_{k+1}=-\boldsymbol{D} \boldsymbol{s}_{k}+\boldsymbol{D} \overline{\boldsymbol{y}}_{k}=-\boldsymbol{D} \boldsymbol{s}_{k}+\boldsymbol{D} \overline{\boldsymbol{C}} \overline{\boldsymbol{x}}_{k}+\boldsymbol{D} \overline{\boldsymbol{C}}_{f} \boldsymbol{f}_{s, k}+\boldsymbol{D} \overline{\boldsymbol{W}_{2}} \boldsymbol{w}_{k}
$$

Thus, an extended state vector can be defines as:

$$
\boldsymbol{x}_{k+1}=\left[\begin{array}{c}
\overline{\boldsymbol{x}}_{k+1} \\
\boldsymbol{s}_{k+1}
\end{array}\right]=\boldsymbol{A} \boldsymbol{x}_{k}+\boldsymbol{B} \boldsymbol{u}_{k}+\boldsymbol{L} \boldsymbol{f}_{k}+\boldsymbol{W} \boldsymbol{w}_{k}
$$

where:

$$
\begin{gathered}
\boldsymbol{f}_{k}=\left[\begin{array}{l}
\boldsymbol{f}_{a, k} \\
\boldsymbol{f}_{s, k}
\end{array}\right], \boldsymbol{A}=\left[\begin{array}{cc}
\overline{\boldsymbol{A}} & 0 \\
\boldsymbol{D} \overline{\boldsymbol{C}} & -\boldsymbol{D}
\end{array}\right], \boldsymbol{B}=\left[\begin{array}{c}
\overline{\boldsymbol{B}} \\
0
\end{array}\right], \\
\boldsymbol{L}=\left[\begin{array}{cc}
\overline{\boldsymbol{B}} & 0 \\
0 & \boldsymbol{D} \overline{\boldsymbol{C}_{f}}
\end{array}\right], \boldsymbol{W}=\left[\begin{array}{c}
\overline{\boldsymbol{W}_{1}} \\
\boldsymbol{D} \overline{\boldsymbol{W}_{2}}
\end{array}\right] .
\end{gathered}
$$

While the corresponding output equation is:

$$
\boldsymbol{y}_{k}=\boldsymbol{C} \boldsymbol{x}_{k}
$$

with

$$
\boldsymbol{C}=\left[\begin{array}{ll}
\mathbf{0} & \boldsymbol{I}
\end{array}\right]
$$

It can be observed that the problem of estimating $\overline{\boldsymbol{x}}_{k}, \boldsymbol{f}_{a, k}$ and $\boldsymbol{f}_{s, k}$ was reduced to estimating $\boldsymbol{x}_{k}$ and $\boldsymbol{f}_{k}$ described by (10)(11), respectively. This allows direct application of the scheme (3)-(5). As a result, the proposed approach is able simultaneously estimate sensor and actuator faults but it cannot be applied for the process fault. Indeed, the process fault can be described as follows:

$$
\begin{gathered}
\boldsymbol{x}_{k+1}=\left(\boldsymbol{A}+\sum_{i=1}^{n_{p}} A_{i, f} \boldsymbol{f}_{p, i}\right) \boldsymbol{x}_{k}+\boldsymbol{B} \boldsymbol{u}_{k}+\boldsymbol{B} \boldsymbol{f}_{a, k}+\boldsymbol{W}_{1} \boldsymbol{w}_{k} \\
\boldsymbol{y}_{k}=\boldsymbol{C} \overline{\boldsymbol{x}}_{k}+\boldsymbol{C}_{f} \boldsymbol{f}_{s, k}+\boldsymbol{W}_{2} \boldsymbol{w}_{k}
\end{gathered}
$$

where $f_{p, i}$ stands for the $i$-th process fault. An immediate observation of the above system description leads to the conclusion that, even for linear system, the process fault estimation problem is a nonlinear one. Indeed, the multiplication between fault and state in (12), i.e., $\boldsymbol{f}_{p, i} \boldsymbol{x}_{k}$ clearly justifies this conclusion. A research on multiplicative fault detection and estimation was realized using sliding mode observers [47], adaptive observers for linear and nonlinear systems [48, 32, 49] as well as for linear parameter-varying ones [50].

Unfortunately, up to the authors knowledge, there is no solution present in the literature that is able to clearly identify the source of a fault and to provide its accurate estimate. Irrespective of the above unappealing phenomenon, the objective of the subsequent part is to discuss recent developments in the area of fault compensation and accommodation.

\section{Fault Compensation and Accommodation}

Recently, a number of books was published in the last decade on the emerging problem of the FTC. In particular, the book [7] is mainly devoted to fault diagnosis while providing some general rules for the hardware-redundancy-based FTC. On the contrary, the work [8] introduces the concepts of the active and passive FTC. It also investigates the problem of performance and stability of the FTC under imperfect (delayed and imprecise) fault diagnosis. In particular, the authors consider (under a chain of some, not necessarily easy to satisfy assumptions) the effect of a delayed fault detection and an imperfect fault identification but the fault diagnosis scheme is treated separately during the design and no real integration of the fault diagnosis and the FTC is proposed. The FTC is also treated in a very interesting

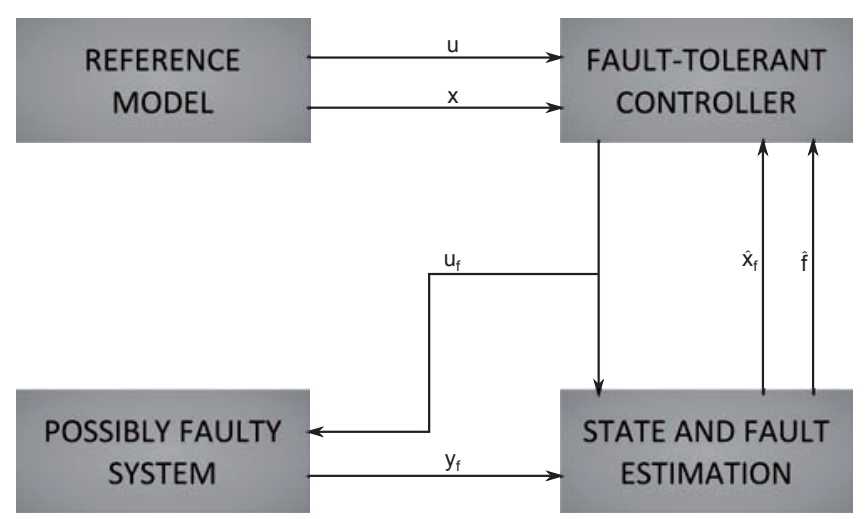

Fig. 8. Virtual actuator-based fault compensation Rys. 8. Kompensacja uszkodzeń bazująca na wirtualnym urządzeniu wykonawczym 


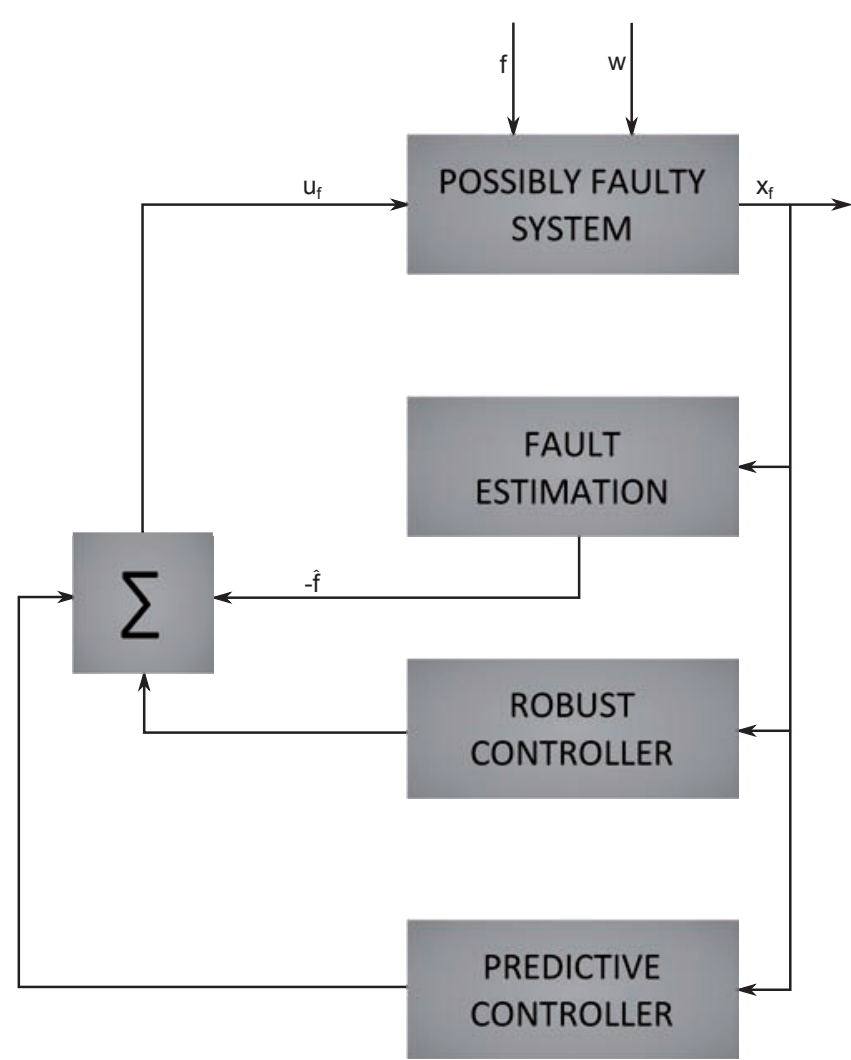

Fig. 9. Virtual actuator-based fault compensation and accommodation Rys. 9. Kompensacja i akomodacja uszkodzeń bazująca na wirtualnym uszkodzeniu wykonawczym

work [9] where the number of practical case studies of FTC is presented, i.e., a winding machine, a three-tank system, and an active suspension system. Unfortunately, in spite of the incontestable appeal of the proposed approaches the FTC integrated with the fault diagnosis is not studied.

As it was the case in the preceding section, let us start with the actuator faults. The idea of integrating fault estimation, compensation and control for the nonlinear system (1)-(2) was introduced in [51]. The approach is depicted in Fig. 8.

The control strategy is given as follows:

$$
\boldsymbol{u}_{f, k}=-\hat{\boldsymbol{f}}_{k}+\boldsymbol{K}_{1}\left(\boldsymbol{x}_{k}-\hat{\boldsymbol{x}}_{f, k}\right)+\boldsymbol{K}_{2}\left[g\left(\boldsymbol{x}_{k}\right)-g\left(\hat{\boldsymbol{x}}_{f, k}\right)\right]+\boldsymbol{u}_{k}
$$

where $\boldsymbol{x}_{k}$ and $\boldsymbol{u}_{k}$ are the reference state and input, respectively. While $\hat{\boldsymbol{x}}_{f, k}, \hat{\boldsymbol{f}}_{k}$ are the state and fault estimates of the faulty system. The design strategy boils down to compensating the effect of a fault in such a way as the faulty state follows the reference one. The strategy is composed of the nominal nonlinear controller (with gains $\boldsymbol{K}_{1}$ and $\boldsymbol{K}_{2}$ ) and the fault compensator $-\hat{\boldsymbol{f}}_{k}$. Thus, in the light of the above discussion, it can be perceived as a virtual actuator. However, if fault compensation cannot be realized within the required range then the proposed approach will lead to the divergence from the reference state.

The approach proposed in [52], tackles the above-mentioned difficulties by providing an elegant way of incorporating actuator fault diagnosis (particularly the fault identification) into the fault-tolerant control framework. The proposed approach is based on a triple stage procedure. It starts from actuator fault estimation, then the fault is compensated with a robust controller. Finally, if the fault compensation does not provide satisfactory results, which means that the current state does not

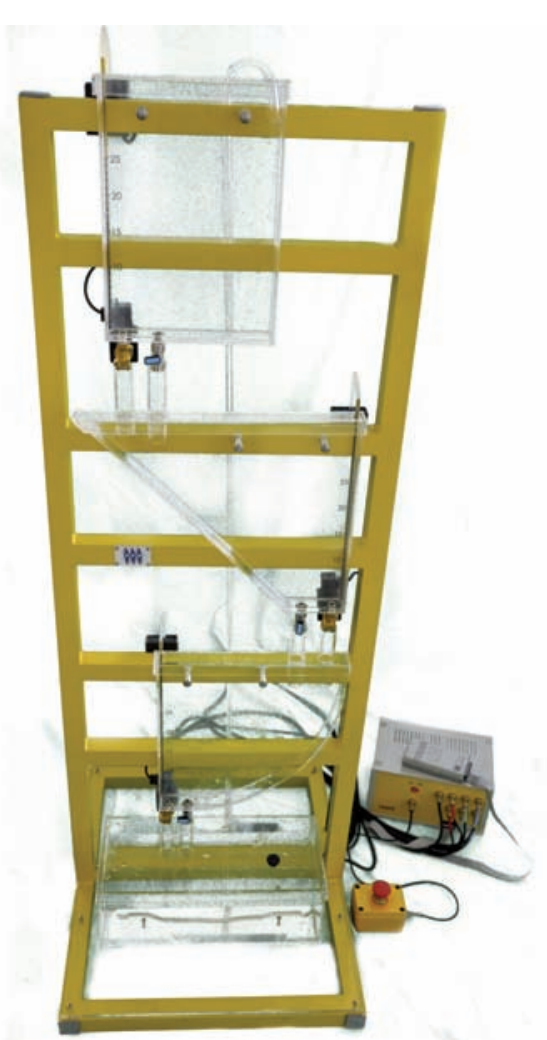

Fig. 10. Multi-tank system

Rys. 10. Układ wielu zbiorników

belong to the robust invariant set, then a suitable predictive control actions are performed in order to enhance the invariant set. This appealing phenomenon makes it possible to enlarge the domain of attraction, which makes the proposed approach an efficient solution. The crucial issue is to maintain the state of the system inside the robust invariant feasible set, which is a set of states guaranteeing the stability of the proposed control strategy. The overall scheme of the approach is given in Fig. 9.

The proposed control scheme, which is a combination of the fault-compensation [51] and predictive control [53] schemes is as follows:

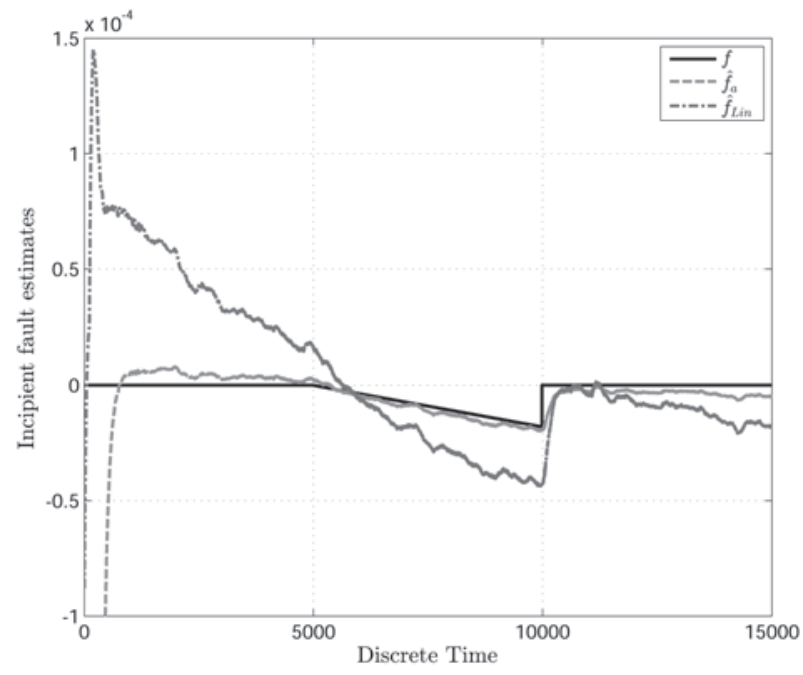

Fig. 11. Incipient fault estimated with linear and robust UIO Rys. 11. Uszkodzenie powoli narastające estymowane przy użyciu liniowego obserwatora i odpornego obserwatora o nieznanym wejściu 


$$
\boldsymbol{u}_{f, k}=-\boldsymbol{K} \boldsymbol{x}_{k}-\hat{\boldsymbol{f}}_{k-1}+\boldsymbol{c}_{k}
$$

while the predicted future input corresponds to the finite horizon optimization that has to be activated when the input constraints are close to be violated by the fault compensation mechanism. This means that the remaining actuators should be suitably activated in order to compensate the effect of a faulty actuator. In particular it is described by:

$$
\boldsymbol{u}_{f, j}= \begin{cases}-\boldsymbol{K} \boldsymbol{x}_{j}-\hat{\boldsymbol{f}}_{k-1}+\boldsymbol{c}_{j}, & j=k, \ldots, k+n_{c}-1, \\ -\boldsymbol{K} \boldsymbol{x}_{j}-\hat{\boldsymbol{f}}_{k-1}, & j \geq k+n_{c}\end{cases}
$$

where:

$-n_{c}$ is the prediction horizon,

$-\boldsymbol{K}$ is the $H_{\infty}$ controller designed to achieve robustness with respect to exogenous disturbances and fault estimation uncertainty,

$-\hat{\boldsymbol{f}}_{k-1}$ is the fault estimate, which compensates the effect of a fault,

$\boldsymbol{-} \boldsymbol{c}_{j}$ is a vector introducing additional design freedom, which should be exploited when the fault compensation along with robust control do not provide expected results indicated by going outside an invariant set.

Thus, the presented scheme enhances the abilities of the approach [51] by enabling appropriate control actions $\boldsymbol{c}_{k}$ when the fault compensation does not provide required results. This scheme can also be perceived as a virtual actuator with $\boldsymbol{K}$ being a nominal controller and $\hat{\boldsymbol{f}}_{k}$ and $\boldsymbol{c}_{k}$ provide appropriate fault compensation and accommodation actions. It should be also pointed out that the proposed approach was extended to cope with nonlinear systems described in the Takagi-Sugeno framework [54].

As it was already mention, the design of virtual sensors rely on replacing measurements provided by faulty system with their estimates. This means that the fault of a sensor cannot lead to the loss of observability property of the entire system, which means that a suitably moderated hardware must be ensured. The implementation of on-line observability tests for linear systems is very easy and straightforward while for nonlinear sys-

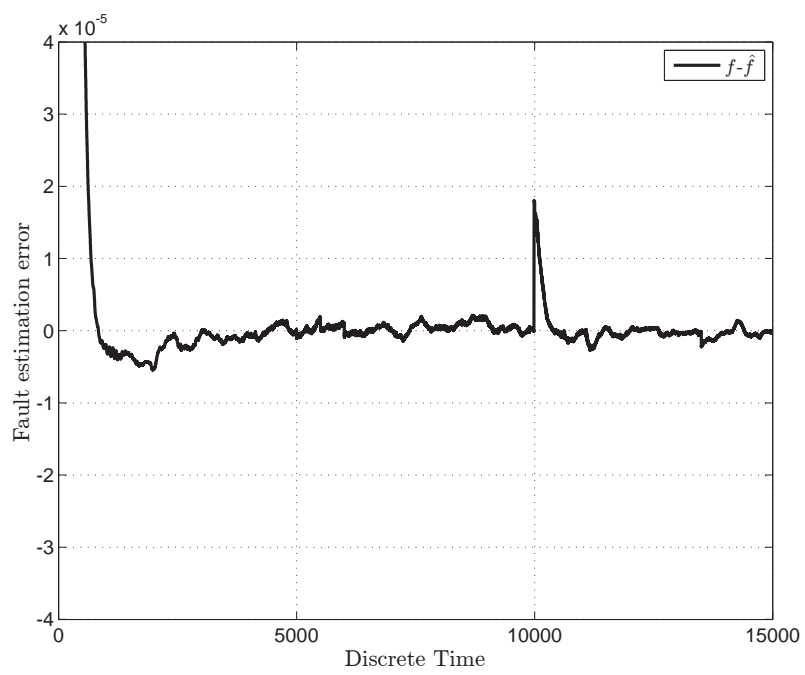

Fig. 12. Fault estimation error

Rys. 12. Błąd estymacji uszkodzenia tem it constitutes a significant challenge. To summarize, the virtual actuator can be realized by a simple output feedback controller of the form:

$$
\boldsymbol{u}_{f, k}=-\boldsymbol{K} \hat{\boldsymbol{x}}_{k}
$$

Finally, it is an obvious fact that process faults can be accommodated in a similar fashion as those of actuators. However, fault compensation depends on the type of the fault and cannot be written in an universal fashion.

\subsection{Illustrative Example - Fault Estimation}

In order to show the effectiveness of the presented fault estimation approach the multi-tank system presented in Fig. 10 is chosen. Such a system is designed for simulating the real industrial multi-tank systems in the laboratory conditions [59]. It consists of three separate tanks placed each above other and equipped with drain valves and level sensors based on a hydraulic pressure measurement. Each of them has a different cross-section in order to reflect system nonlinearities. The lower bottom tank is a water reservoir for the system. A variable speed water pump is used to fill the upper tank. The water outflows the tanks due to gravity. The considered multi-tank system has been designed to operate with an external, PC-based digital controller. The control computer communicates with the level sensors, valves and a pump by a dedicated I/O board and the power interface. The I/O board is controlled by the real-time software, which operates in a MATLAB/Simulink environment. For further information the reader is referred to the INTECO manufacturer documentation.

Let us consider the following fault scenario, which can be perceived as a decrease of the pump efficiency:

- incipient fault:

$$
f_{a, k}=f(x)=\left\{\begin{array}{cc}
-0.2(k+500) u_{k}, & 5000 \leq k \leq 10000 \\
0, & \text { otherwise }
\end{array}\right.
$$

All of experiments were performed with real system exclusively.

Figure 11 presents the result of the incipient fault estimation obtained with robust UIO and linear observer. It is easy to

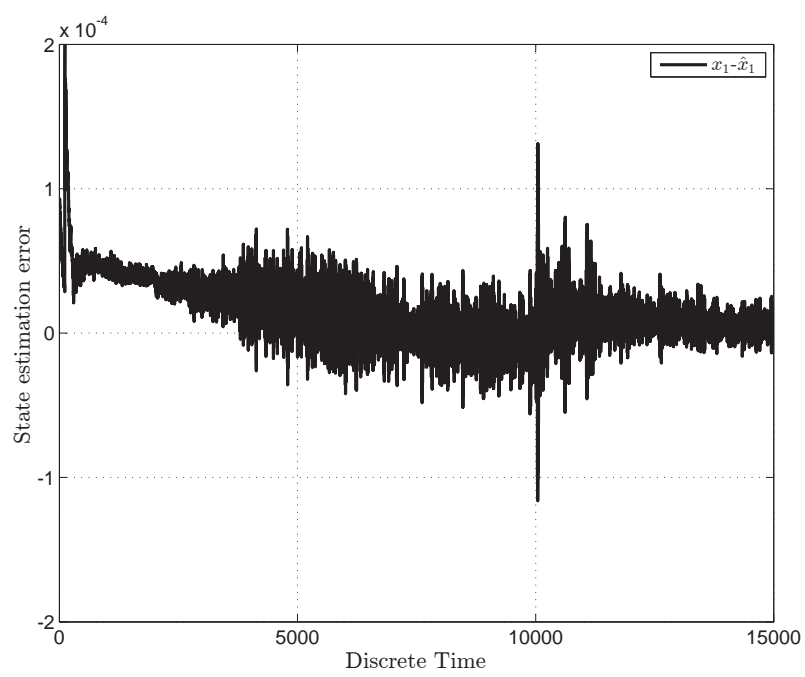

Fig. 13. State estimation error - first tank

Rys. 13. Błąd estymacji stanu - pierwszy zbiornik 


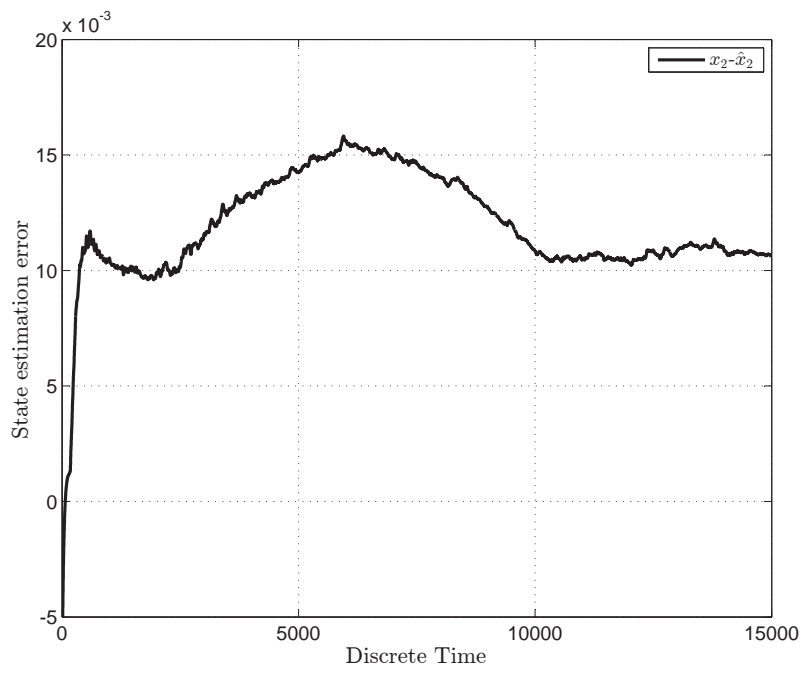

Fig. 14. State estimation error - second tank Rys. 14. Błąd estymacji stanu - drugi zbiornik

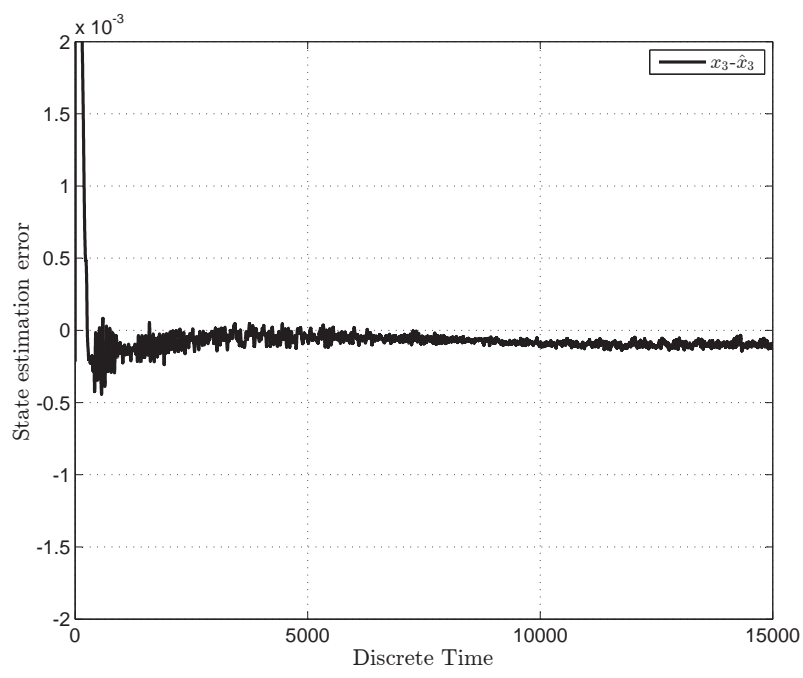

Fig. 15. State estimation error - third tank

Rys. 15. Błąd estymacji stanu - trzeci zbiornik

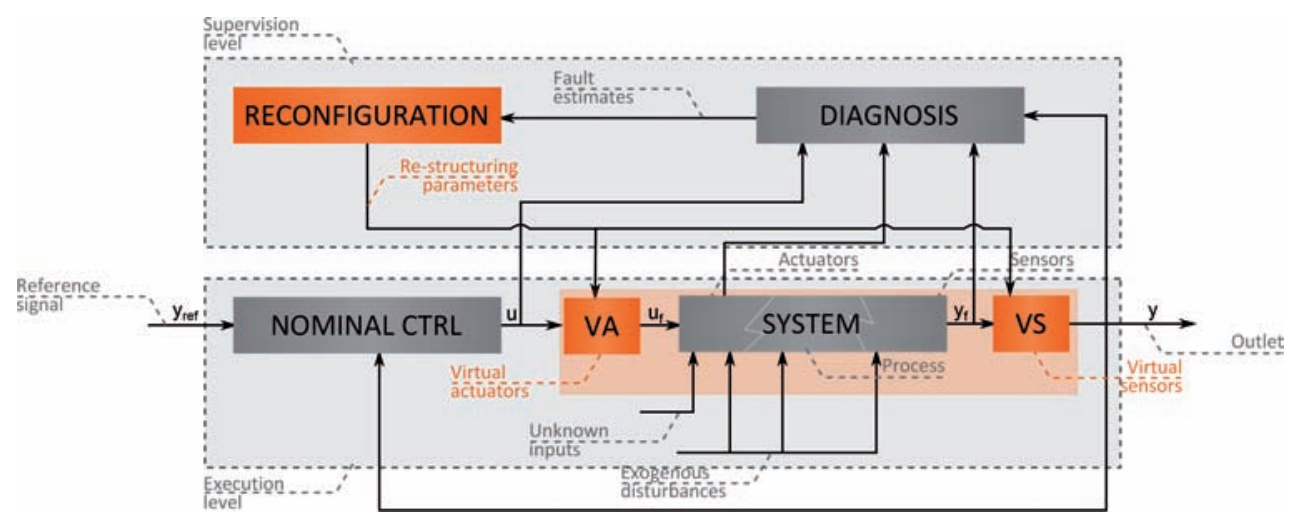

Fig. 16. Cooperative virtual sensors and actuators

Rys. 16. Kooperujące wirtualne czujniki i urządzenia wykonawcze

observe that the fault is estimated with relatively small error, which is depicted in Fig. 12.

The robust UIO estimates the incipient fault much better than the linear one.

Figures $13-15$ present the state estimation errors in the first, second and third tank, respectively.

The presented results clearly indicated that high quality fault and state estimation can be achieved in real conditions with the presented approach. This recommends to apply the proposed approach in industrial conditions. Moreover, it can be further integrated with the approaches proposed in [52, 53]. Due to the lack of space, the preliminary results regarding virtual actuator design exposed in $[52,53]$ are not presented in this paper and, for further details, the reader is referred to these references.

\section{Challenges: Cooperative Virtual Sensors and Actuators}

As it was already mentioned, several recent works threats the virtual sensing or actuation separately $[55,56]$, even if they work simultaneously. Moreover, the possible process faults are usually neglected and the approaches are dedicated to either sensor or actuator faults, respectively. In particular [56], uses the virtual sensors-actuators arrays only in terms of collocation of sensors in the middleware [55, 57], does not consider process faults, similarly as in [58]. This observations leads to the novelty of proposed research direction that can be reflected in a cooperative virtual sensors and actuator schemes. Such an approach can also be employed to exclude sensor/actuator fault and to realize process fault estimation and accommodation in an efficient way. Taking into account the discussion provided in the preceding part of this paper, it can be concluded that both virtual sensors and virtual actuators strategies can be used independently. However, the cooperative scheme has to be introduced in order to detect and accommodate the process faults and to enhance the overall effectiveness of the Fault Detection and Isolation (FDI) and FTC. Indeed, most of the works present in the literature are devoted to either virtual sensor or virtual actuator design, respectively. This is of course under the assumption that either all sensors or actuators are fault-free. The situation is even worst when process faults are taken into account. Thus, the cooperative scheme joining advantages of virtual sensors and actuators should be perceived as a good remedy to this problem (Fig. 16).

Due to the fact that all industrial systems grow rapidly, FTC systems are commonly studied nowadays, both from theoretical and practical viewpoints $[11,15]$. Vast publication 
record witnesses growing demands and expectations for the FTC and FDI. Despite the above facts, there are still many unsolved mathematical issues and a wide area of multidisciplinary engineering application on the cross-section of control, computing and signal processing. In the light of the stateof-the art, the integrated FTC and FDI working within an uncertain environment is still a meaningful and open problem. The integration should incorporate the constraints of the system and control variables, the cost function describing quality of control, and also restrain the effects of disturbances and noises. All the above, severely increase the complexity of the problem stated while making the solutions more universal and reliable. The cooperative scheme of virtual actuators and virtual sensors has not been yet investigated. Thus, the pioneering nature of the research can be justified by the fact that such an approach can also be employed to exclude sensor/actuator fault and to realize process fault estimation and accommodation in an efficient way. Such an approach has never been treated in the literature. Due to this fact, its novelty becomes evident. Its realization requires an application of the new approaches taking advantages of an advanced analysis of stability, observability and controllability. The proposed research framework is based on few main objectives. Firstly, new theoretical approaches will be developed using the general virtual sensor and actuator approach, which constitute the base for the realization of the second part devoted to cooperative scheme. Finally, the above approaches will be used to estimate the actuator, sensor and process faults simultaneously and then to accommodate their impact with an appropriate control action. The proposed solutions constitute an answer for the unsolved problems that can be summarized as follows: - Modelling and robust estimation of lost of effectiveness due to actuator malfunctions (faulty situations) and the design of virtual actuators adapting the control strategy to new conditions within the uncertain environment.

- Virtual sensor design for the validation of inconsistent sensor data: minimize the risk with the inconsistent measurement that may have serious consequences for the system performance.

- Integration of virtual actuator and sensor-based FTC with the fusion of analytical modeling techniques account the constraints related with the non-linear system and its control variables.

- Development of process faults estimation technique along with sensor and actuator fault estimation and compensation.

\section{Conclusions}

The main objective of this paper was to review recent advances in the area of fault-tolerant control. In particular, starting from essentials of fault diagnosis, the reader is introduced to robust FTC. Subsequently, more advanced active FTC schemes are introduced and their advantages and drawback are discussed. The preliminary part ends with the advanced virtual sensors and actuators schemes. The remaining part of the paper is devoted to the presentation of the recent results achieved by the authors in the emerging area of FTC. In particular, the advanced fault estimation scheme is described and then virtual actuators schemes are discussed. The paper ends with a discussion regarding the future of FTC, which is related to the cooperative virtual sensors and actuators capable of handling simultaneous actuator, sensor and process faults.

\section{References}

1. Blanke M., Kinnaert M., Lunze J., Staroswiecki M., Diagnosis and Fault-Tolerant Control, Springer-Verlag, New York 2006, DOI: 10.1007/978-3-540-35653-0.
2. Chen J., Patton R.J., Robust Model-Based Fault Diagnosis for Dynamic Systems, Kluwer Academic Publishers, London 1999, DOI: 10.1007/978-1-4615-5149-2.

3. Isermann R., Fault-Diagnosis Systems. An Introduction from Fault Detection to Fault Tolerance, Springer-Verlag, New York 2006, DOI: 10.1007/3-540-30368-5.

4. Kościelny J., Diagnostics of Automatic Industrial Processes, Academic Publishing Office EXIT, Warsaw 2001.

5. Korbicz J., Kościelny J.M., Kowalczuk Z., Cholewa W. (Eds.), Fault Diagnosis. Models, Artificial Intelligence, Applications, Springer-Verlag, Berlin 2004, DOI: 10.1007/978-3-642-18615-8.

6. Witczak M., Modelling and Estimation Strategies for Fault Diagnosis of Non-linear Systems, Springer-Verlag, Berlin 2007, DOI: 10.1007/978-3-540-71116-2.

7. Isermann R., Fault-Diagnosis Applications: Model-Based Condition Monitoring, Actuators, Drives, Machinery, Plants, Sensors, and Fault-tolerant Systems, Springer-Verlag, Berlin 2011, DOI: 10.1007/978-3-642-12767-0.

8. Mahmoud M., Jiang J., Zhang Y., Active Fault Tolerant Control Systems. Stochastic Analysis and Synthesis, Springer-Verlag, Berlin 2003, DOI: 10.1007/3-54036283-5.

9. Noura H., Theilliol D., Ponsart J., Chamseddine A., Fault-tolerant Control Systems. Design and Practical Applications, Springer-Verlag, Berlin 2009, DOI: 10.1007/978-1-84882-653-3.

10. Ducard G., Fault-tolerant Flight Control and Guidance Systems: Practical Methods for Small Unmanned Aerial Vehicles, Springer-Verlag, Berlin 2009, DOI: 10.1007/9781-84882-561-1.

11. Witczak M., Fault Diagnosis and Fault-Tolerant Control Strategies for Non-Linear Systems. Analytical and Soft Computing Approaches, Springer International Publishing, Heidelberg 2014, DOI: 10.1007/978-3-319-03014-2.

12. Korbicz J., Kościelny J.M. (Eds.), Modeling, Diagnostics and Process Control. Implementation in the DiaSter System, Springer-Verlag, Berlin 2011, DOI: 10.1007/9783-642-16653-2.

13. Witczak M., Advances in model-based fault diagnosis with evolutionary algorithms and neural networks, "International Journal of Applied Mathematics and Computer Science", Vol. 16, No. 1, 2006, 85-99.

14. Blanke M., Bøgh S., Jørgensen R.B., Patton R.J., Fault detection for diesel engine actuator. A benchmark for FDI, "Control Engineering Practice", Vol. 3, No. 12, 1995, 1731-1740, DOI: 10.1016/0967-0661(95)96891-R.

15. Zhang Y., Jiang J., Bibliographical review on reconfigurable fault-tolerant control systems, "Annual Reviews in Control", Vol. 32, No. 2, 2008, 229-252, DOI: 10.1016/j. arcontrol.2008.03.008.

16. Zhang Y., Jiang J., Bibliographical review on reconfigurable fault-tolerant control systems, [in:] Proceedings of the $5^{\text {th }}$ IFAC Symposium Fault Detection Supervision and Safety of Technical Processes, SAFEPROCESS, Washington, D.C., USA 2003, 265-276.

17. Liang Y., Liaw D., Lee T., Reliable control of nonlinear systems, "IEEE Transactions on Automatic Control", Vol. 45, No. 4, 2000, 706-710, DOI: 10.1109/9.847106.

18. Liao F., Wang J., Yang G., Reliable robust flight tracking control: an LMI approach, "IEEE Transactions on Control Systems Technology", Vol. 10, No. 1, 2000, 76-89, DOI: $10.1109 / 87.974340$.

19. Qu Z., Ihlefeld C., Yufang J., Saengdeejing A., Robust fault-tolerant self-recovering control of nonlinear uncertain systems, "Automatica", Vol. 39, No. 10, 2003, 1763-1771, DOI: 10.1016/S0005-1098(03)00181-X. 
20. Li H., Zhao Q., Yang Z., Reliability modeling of fault tolerant control systems, "International Journal of Applied Mathematics and Computer Science", Vol. 17, No. 4, 2007, 491-504, DOI: 10.2478/v10006-007-0041-0.

21. Blanke M., Kinnaert M., Lunze J., Staroswiecki M., Diagnosis and Fault-Tolerant Control. Second Edition. Springer-Verlag Berlin Heidelberg, 2006, DOI: 10.1007/978-3-540-35653-0.

22. Dziekan L., Witczak M., Korbicz J., Active fault-tolerant control design for Takagi-Sugeno fuzzy systems, "Bulletin of the Polish Academy of Sciences: Technical Sciences", Vol. 59, No. 1, 2011, 93-102.

23. Madria S., Kumar V., Dalvi R., Sensor cloud: A cloud of virtual sensors, "IEEE Software", Vol. 31, No. 2, 2014, 70-77.

24. Seron M.M., De Dona J.A., Fault tolerant control using virtual actuators and invariant-set based fault detection and identification, [in:] Decision and Control, 2009 held jointly with the 2009 28th Chinese Control Conference. CDC/CCC 2009. Proceedings of the 48th IEEE Conference on. IEEE, 2009, 7801-7806, DOI: 10.1109/ CDC.2009.5399909.

25. Rotondo D., Puig V., Nejjari F., Romera J., A fault-hiding approach for the switching quasi-LPV fault tolerant control of a four-wheeled omnidirectional mobile robot, "IEEE Transactions on Industrial Electronics", Vol. 62, No. 6, 2015, 3932-3944, DOI: 10.1109/TIE.2014.2367002.

26. Pratt J., Torres A., Dilworth P., Pratt G., Virtual actuator control, [in:] Proceedings of the 1996 IEEE/RSJ International Conference on Intelligent Robots and Systems' 96, IROS 96, Vol. 3. IEEE, 1996, 1219-1226, DOI: 10.1109/ IROS.1996.568974.

27. Pawlowski A., Cervin A., Guzman J.L., Berenguel M., Generalized predictive control with actuator deadband for event-based approaches, "IEEE Transactions on Industrial Informatics", Vol. 10, No. 1, 523-537, 2014, DOI: 10.1109/ TII.2013.2270570.

28. Shin J., Kurdahi F., Dutt N., Cooperative on-chip temperature estimation using multiple virtual sensors, "IEEE Embedded Systems Letters", Vol. 7, No. 2, 2015, DOI: 10.1109/LES.2015.2400992.

29. Keller J.Y., Darouach M., Two-stage Kalman estimator with unknown exogenous inputs, "Automatica", Vol. 35, No. 2, 1999, 339-342, DOI: 10.1016/S0005-1098(98)00194-0.

30. Gillijns S., De Moor B., Unbiased minimum-variance input and state estimation for linear discrete-time systems, "Automatica", Vol. 43, No. 1, 2007, 111-116, DOI: 10.1016/j.automatica.2006.08.002.

31. Khémiri K., Ben Hmida F., Ragot J., Gossa M., Novel optimal recursive filter for state and fault estimation of linear systems with unknown disturbances, "International Journal of Applied Mathematics and Computer Science", Vol. 21, No. 4, 629-637, 2011, DOI: 10.2478/v10006-0110049-3.

32. Zhang X., Polycarpou M., Parisini T., Fault diagnosis of a class of nonlinear uncertain systems with Lipschitz nonlinearities using adaptive estimation, "Automatica", Vol. 46, No. 2, 2010, 290-299, DOI: 10.1016/j.automatica.2009.11.014.

33. Veluvolu K.C., Kim M.Y., Lee D., Nonlinear sliding mode high-gain observers for fault estimation, "International Journal of Systems Science", Vol. 42, No. 7, 2011, 1065-1074, DOI: 10.1080/00207721.2011.573102.

34. Nobrega E.G., Abdalla M.O., Grigoriadis K.M., Robust fault estimation of uncertain systems using an LMI-based approach, "International Journal of Robust and Nonli- near Control", Vol. 18, No. 18, 2008, 1657-1680, DOI: 10.1002/rnc.1313.

35. Rotondo D., Nejjari F., Puig V., A virtual actuator and sensor approach for fault tolerant control of LPV systems, "Journal of Process Control", Vol. 24, No. 3, 2014, 203-222, DOI: 10.1016/j.jprocont.2013.12.016.

36. Ichalal D., Marx B., Ragot J., Maquin D., Fault detection, isolation and estimation for Takagi-Sugeno nonlinear systems, "Journal of the Franklin Institute", Vol. 351, No. 7, 2014, 3651-3676, DOI: 10.1016/j.jfranklin.2013.04.012.

37. Seron M.M., De Doná J.A., Robust fault estimation and compensation for LPV systems under actuator and sensor faults, "Automatica", Vol. 52, 2015, 294-301, DOI: 10.1016/j.automatica.2014.12.003.

38. Tabatabaeipour S.M., Bak T., Robust observer-based fault estimation and accommodation of discrete-time piecewise linear systems, "Journal of the Franklin Institute", Vol. 351, No. 1, 2014, 277-295, 10.1016/j.jfranklin.2013.08.021.

39. De Persis C., De Santis R., Isidori A., Nonlinear actuator fault detection and isolation for a VTOL aircraft, [in:] Proceedings of the 2001 American Control Conference, 2001, 4449-4454, DOI: 10.1109/ACC.2001.945679.

40. Amato F., Cosentino C., Mattei M., Paviglianiti G., A mixed direct/functional redundancy scheme for the FDI on a small commercial aircraft, [in:] Proceedings of the SAFEPROCESS03, IFAC Symposium, 2003, 167-172.

41. Hammouri H., Kinnaert M., El Yaagoubi E.H., Observer-based approach to fault detection and isolation for nonlinear systems, "IEEE Trans. on Automatic Control", Vol. 44, No. 10, 1999, 1879-1884, DOI: 10.1109/9.793728.

42. De Persis C., Isidori A., An H_infty-suboptimal fault detection filter for bilinear systems, [in:] Proceedings of the Nonlinear Control in the Year 2000, 331-339, 2000, DOI: $10.1007 / \mathrm{BFb} 0110224$.

43. De Persis C., A. Isidori, A geometric approach to nonlinear fault detection and isolation, "IEEE Transactions on Automatic Control", Vol. 46, No. 6, 853-865, 2001, DOI: 10.1109/9.928586.

44. Mattei M., Paviglianiti G., Scordamaglia V., Nonlinear observers with $H$ _ infty performace for sensor fault detection and isolation: a linear matrix inequality design procedure, "Control Engineering Practice", Vol. 13, No. 10, 2006, 1271-1281, DOI: 10.1016/j.conengprac.2004.11.012.

45. Mrugalski M., An unscented Kalman filter in designing dynamic GMDH neural networks for robust fault detection, "International Journal of Applied Mathematics and Computer Science", Vol. 23, No. 1, 2013, 157-169, DOI: 10.2478/amcs-2013-0013.

46. Witczak M., Buciakowski M., Puig V., Rotondo D., Nejjari F., An LMI approach to robust fault estimation for a class of nonlinear systems, "International Journal of Robust and Nonlinear Control", 2015, DOI: 10.1002/rnc.3365.

47. Tan C., Edwards C., Multiplicative fault reconstruction using sliding mode observers, [in:] Asian Control Conference, Vol. 2, 2004, 957-962.

48. Chunyan G., Qing Z., Guang-Ren D., Multiplicative fault estimation for a type of nonlinear uncertain system, [in:] $30^{\text {th }}$ Chinese Control Conference, IEEE, 2011, 4355-4360.

49. Gao C., Duan G., Robust adaptive fault estimation for a class of nonlinear systems subject to multiplicative faults, "Circuits, Systems, and Signal Processing", Vol. 31, No. 6, 2012, 2035-2046, 10.1007/s00034-012-9434-x.

50. Shi F., Patton R., A robust adaptive approach to wind turbine pitch actuator component fault estimation, [in:] 2014 UKACC International Conference on Control, IEEE, 468-473, DOI: 10.1109/CONTROL.2014.6915185. 
51. Witczak M., Puig V., de Oca S., A fault-tolerant control strategy for non-linear discrete-time systems: application to the twin-rotor system, "International Journal of Control", Vol. 86, No. 10, 2013, 1788-1799, DOI: 10.1080/00207179.2013.796592.

52. Witczak M., Buciakowski M., Aubrun C., Predictive actuator fault-tolerant control under ellipsoidal bounding, "International Journal of Adaptive Control and Signal Processing", 2015, DOI: 10.1002/acs.2567.

53. Kouvaritakis B., Rossiter J.A., Schuurmans J., Efficient robust predictive control, "IEEE Transactions on Automatic Control", Vol. 45, No. 8, 2000, 1545-1549, DOI: 10.1109/9.871769.

54. Witczak P., Witczak M., Korbicz J., Aubrun Ch., A robust predictive actuator fault-tolerant control scheme for Takagi-Sugeno fuzzy systems, "Bulletin of the Polish Academy of Sciences: Technical Sciences", Vol. 63, No. 4, 977-987, 2015.

55. Odgaard P.F., Stoustrup J., A benchmark evaluation of fault tolerant wind turbine control concepts, "IEEE Transactions on Control Systems Technology", Vol. 23, No. 3, 1221-1228, 2015, DOI: 10.1109/TCST.2014.2361291.
56. Zhang H., Krogh B., Moura J.M., Zhang W., Estimation in virtual sensor-actuator arrays using reduced-order physical models, [in:] 43 ${ }^{\text {rd }}$ IEEE Conference on Decision and Control, Vol. 4, 2004, 3792-3797, DOI: 10.1109/ CDC.2004.1429329.

57. Modirnia R., Boulet B., Model-based virtual sensors and core-temperature observers in thermoforming applications, "IEEE Transactions on Industry Applications", Vol. 49, No. 2, 721-730, 2013, DOI: 10.1109/TIA.2013.2244544.

58. Gosiewski Z., Kulesza Z., Virtual collocation of sensors and actuators for a flexible rotor supported by active magnetic bearings, [in:] $14^{\text {th }}$ International Carpathian Control Conference (ICCC), 2013, 94-99, DOI: 10.1109/CarpathianCC.2013.6560518.

59. [www.inteco.com.pl] INTECO. Multitank System - User's manual, 2013.

\section{Sterowanie tolerujące uszkodzenia: rozwiązania i wyzwania}

Streszczenie: Systemy sterowania tolerującego uszkodzenia FTC (ang. Fault-Tolerant Control) są obecnie intensywnie badane, zarówno z teoretycznego, jak i praktycznego punktu widzenia. Znajduje to odzwierciedlenie w wielu publikacjach naukowych oraz w liczbie międzynarodowych zespołów zaangażowanych w badania nad tym zagadnieniem. FTC jest postrzegane jako technika integrująca zaawansowane strategie diagnostyki uszkodzeń z nowoczesnymi metodami sterowania, umożliwiająca dalsze funkcjonowanie systemu w warunkach uszkodzeń. Teoria diagnostyki uszkodzeń i sterowania jest dobrze rozwinięta i udokumentowana dla systemów liniowych. Istnieją również rozwiązania zmniejszające zależność między jakością funkcjonowania powyższych metod, a niepewnością modelu opisującego sterowany i diagnozowany, która może być spowodowana takimi czynnikami jak: różnice między kopiami użytych elementów konstrukcyjnych, niestacjonarność systemu, zewnętrzne zakłócenia, szumy pomiarowe, itd. Oznacza to, że opracowywanie analogicznych rozwiązań dla systemów nieliniowych jest w pełni uzasadnione. Jedną z głównych trudności w obecnym rozwoje FTC jest fakt, że większość prac prezentowanych w literaturze traktuje problemy diagnostyki uszkodzeń i FTC niezależnie. Niestety, idealna diagnostyka uszkodzeń, a w szczególności ich identyfikacja (określenie rozmiaru uszkodzeń) jest niemożliwa do uzyskania. Uzasadnia to konieczność projektowania zintegrowanych układów diagnostyki i FTC uwzględniających tą niepożądaną właściwość, zarówno dla układów liniowych, jak i nieliniowych. Jak wskazuje przegląd licznych prac w zakresie FTC oraz monografii związanych z tą tematyką, problem integracji jest traktowany bardzo pobieżnie, a jego rozwiązanie zastępuje się szeregiem (zazwyczaj restrykcyjnych) założeń, jakie musi spełniać układ diagnostyczny stanowiący jeden z elementów FTC. Biorąc pod uwagę powyższe uwarunkowania, referat koncentruje się na prezentacji nowoczesnych rozwiązań w zakresie FTC z zastosowaniem technik analitycznych i metod obliczeń inteligentnych. Omawia się również efektywne metody sterowania tolerującego uszkodzenia wraz z procesem integracji układów sterownia i diagnostyki uszkodzeń. 


\section{Marcin Witczak, Ph.D., D.Sc.}

M.Witczak@issi.uz.zgora.pl

Marcin Witczak was born in Poland in 1973, received the M.Sc. degree in electrical engineering from the University of Zielona Góra (Poland), the Ph.D. degree in automatic control and robotics from the Wrocław University of Technology (Poland), and the D.Sc. degree in electrical engineering from the University of Zielona Góra, in 1998, 2002 and 2007, respectively. In 2015 he received a full professorial title. Marcin Witczak has been

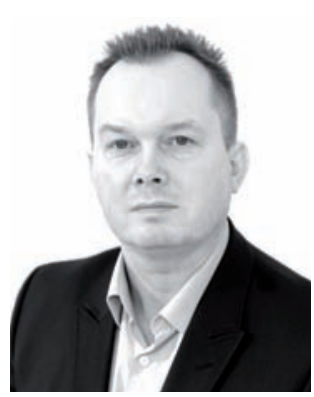
an associate professor of automatic control and robotics at the Institute of Control and Computation Engineering, University of Zielona Góra, Poland, since 2008. His current research interest include computational intelligence, fault detection and isolation (FDI), fault-tolerant control (FTC), as well as experimental design and control theory Marcin Witczak has published more than 140 papers in international journals and conference proceedings. He is an author of 4 monographs and 19 book chapters. Since 2015, he is a member of the Control Engineering and Robotics Commission of the Polish Academy of Sciences.

\section{Marcin Pazera, M.Sc., Eng.}

M.Pazera@issi.uz.zgora.p

Marcin Pazera was born in Poland in 1990 He received the M.Sc. degree in Control Engineering and Robotics from the University of Zielona Góra (Poland) in 2015. He is currently a Ph.D. student at the Institute of Control and Computation Engineering, University of Zielona Góra. His current research interests include fault detection and isolation (FDI), fault-tolerant control (FTC) as well as experimental design and control theory.

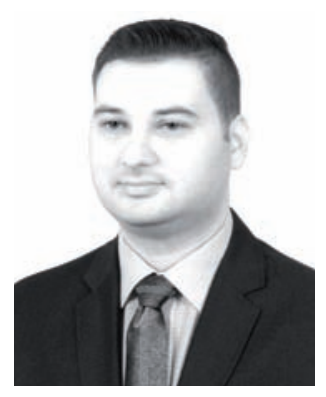

